\title{
Wheat Productivity Under Different Sources and Levels of Nitrogenous Fertilization
}

\author{
Gomaa $^{1}$ M. A., I. F. Rehab ${ }^{1}$, Sohier M. Hassan ${ }^{2}$, Nasra M. A. Kenawy ${ }^{3}$, \\ 1- Plant Production Department, Faculty of Agriculture (Saba Bacha), Alexandria \\ University. \\ 2- Departments Wheat Researches, Field Crops Institute, Agricultural Research \\ Center, El- Beheira. \\ 3- Ministry of Agriculture, Beheria.
}

\begin{abstract}
Two field experiments were carried out at Etay El- Baroud Agricultural Research Station, El- Beheira Governorate during 2013/ 2014 and 2014/2015 seasons to study the effect of three nitrogen sources (Urea, Ammonium sulphate and Ammonium nitrate) and four different levels of nitrogen fertilization $(0,50,75$ and $100 \mathrm{~kg} \mathrm{~N} / \mathrm{fed})$ on some physiological characters, yield and yield components of wheat. Results indicated that days to heading was significantly affected by $\mathrm{N}$ sources in the second season only. While, days to maturity and plant height were insignificantly affected by $\mathrm{N}$ sources in the two seasons. Whereas, days to heading, days to maturity and plant height were significantly increased by increasing nitrogen levels from 0 up to $100 \mathrm{~kg} \mathrm{~N} / \mathrm{fed}$ in the two seasons. Number of spikes $/ \mathrm{m}^{2}$, number of grains/spike, grain weight /spike and 1000- grain weight were gradually and significantly influenced by nitrogen sources in the first and second seasons. The highest number of spikes $/ \mathrm{m}^{2}$ and number of grain/spike were obtained when nitrogen fertilizer added as urea while lowest values obtained when nitrogen fertilizer added as Ammonium sulphate during the two seasons. Whereas, $1000-$ grain weight recorded the highest value at Ammonium nitrate and the lowest at Urea, On the other hand, spike length and number of spikes $/ \mathrm{m}^{2}$ were insignificantly influenced by nitrogen sources in both seasons. All above parameters: were significantly increased by increasing nitrogen levels from zero to $100 \mathrm{~kg} \mathrm{~N} /$ fed during the two studied seasons. The highest values obtained at $100 \mathrm{~kg} \mathrm{~N} / \mathrm{fed}$ while, the lowest ones were obtained under control. Grain, straw and biological yields were significantly influenced by N. sources in the two studied seasons. Urea as sources of $\mathrm{N}$ surpassed on the others sources under study for all studied characters. On the other side, harvest index (\%) was significantly affected by $\mathrm{N}$ sources in the second season only. All other studied parameters were significantly increased by increasing $\mathrm{N}$ levels from zero to $100 \mathrm{~kg} \mathrm{~N} / \mathrm{fed}$ in the two seasons. The heaviest grain, straw and biological yields were given at $100 \mathrm{~kg} \mathrm{~N} / \mathrm{fed}$ while, the lightest at control in the $1^{\text {st }}$ and $2^{\text {nd }}$ seasons. It is important to clear that, the highest value of harvest index (\%) was taken at $75 \mathrm{~kg} \mathrm{~N} / \mathrm{fed}$ and the lowest at control treatment (zero $\mathrm{N}$ ). The interaction between nitrogen sources and $\mathrm{N}$ levels significantly affected, plant height, number of spikes $/ \mathrm{m}^{2}$, grain weight/spike and 1000- grains weight. The highest numbers were taken at $100 \mathrm{~kg} \mathrm{~N} / \mathrm{fed}$ of Urea during the first and the second seasons. Each of straw and biological yield was insignificantly affected by the interaction between nitrogen sources and nitrogen levels in the two studied seasons.
\end{abstract}

Keywords: wheat, yield, yield components, nitrogen fertilization, $\mathrm{N}$ source and levels.

\section{INTRODUCTION}

Wheat (Triticum aestivum L.) is considered to be one of the most important cereal crops in the world as well as in Egypt. It ranks first among the main four crops namely rice, maize and barely. It occupies about $30 \%$ of the world cropping area. It used as human food and animal feed. In Egypt the cultivated area of wheat reached about 3.1 million feddan in 2015/2016 giving 8.2 million tons of grains with a national average of about $18.1 \mathrm{ardab} / \mathrm{fed}$. However, the local consumption in the same year surpassed 14-15 million tons (FAO, 2016). Egypt import about $55 \%$ of its wheat consumption to face the 
great need of the high population increment and the shortage of production and the main target is to approximate between production and consumption. Most of researches conducting to evaluate performance of different sources of nitrogen on yield and yield components of wheat. Mohammed et al. (2015) found that Diammonium phosphate surpassed Ammonium sulphate and Urea in all studied characters. Whereas, Tereza et al. (2012) revealed that grain yield was insignificantly affected by nitrogen sources. Nitrogen fertilization had vital role in increasing yield and yield attributes in various crops especially wheat. Concerning the effect of nitrogen fertilizer levels on wheat grain yield and its attributes, Ahmed et al. (2009) reported that addition of nitrogen fertilizer up to $102 \mathrm{~kg} / \mathrm{fed}$ significantly increased plant height, number of spikes $/ \mathrm{m}^{2}$, spike length, number of grains/ spike, 1000-grains weight, straw yield and grain yield. El- Hawary and Shahein (2015) indicated that application of nitrogen fertilizer up to $105 \mathrm{~kg} \mathrm{~N}$./fed lead to increase number of grain /spike, 1000-grains weight and grain yield (ardab/fed). El- Hag and Shahein (2017) stated that increase in nitrogen fertilizer levels significantly increased number of days to heading and maturity, plant height, spikes $/ \mathrm{m}^{2}$, grains/spike, grains and straw yields and 1000- grains weight.

The objective of this investigation was to study the effect of different sources and levels of nitrogenous fertilization on wheat productivity under ElBeheira conditions.

\section{MATERIALS AND METHODS}

Two field experiments were conducted at Etay El- Baroud Agricultural Research Station, El- Beheira Governorate, Egypt during 2013/2014 and $2014 / 2015$ seasons to study the effect of three nitrogen sources and four nitrogen levels on yield and yield components of wheat (Triticum aestivum L.).

The preceding crop was corn in the two seasons. Soil samples of the experimental sites were taken at the depth of zero to $15 \mathrm{~cm}$ and 15 to $30 \mathrm{~cm}$ from soil surface before sowing. Some physical and chemical analyses were done according to Chapman and Pratt (1978). Detailed results of the soil characteristics are presented in Table (1).

The experimental design was split plot design in three replications. Three sources of nitrogenous fertilization (Urea (46.5\%, Ammonium sulphate $(20.5 \%)$, and Ammonium nitrate (33.5\%)) were randomly allocated in the main plots and four levels of nitrogen fertilization (control (without $\mathrm{N}$ fertilizers), 50, 75 and 100 $\mathrm{kg} \mathrm{N} / \mathrm{fed}$ ) were allocated in the sub- plot.

Each sub plot size was $10.50 \mathrm{~m}^{2}$ (3 $\mathrm{m}$ in length and $3.5 \mathrm{~m}$ in width). The grains of the tested wheat cultivar (Gemiza 11) were obtained from wheat Research Section of Agriculture Research Center, Ministry of Agriculture, Egypt. Sowing dates were $29^{\text {th }}$ and $21^{\text {th }}$ November 2013 and 2014 in both seasons, respectively, while seeding rate was $70 \mathrm{~kg} / \mathrm{fed}$.

The application of nitrogen fertilizer was added in two equal doses, the first one before the first irrigation (21 days after sowing) and the second one

Vol. 23 (4), 2018 
before the second irrigation (21 days later). Phosphorus fertilizer was applied at the rate of $15.5 \mathrm{~kg} \mathrm{P}_{2} \mathrm{O}_{5} / \mathrm{fed}$ (100 kg calcium phosphate) during seed bed preparation. Potassium fertilizer was applied before sowing (during seedbed preparation) at rate of $24 \mathrm{~kg} \mathrm{~K} \mathrm{~K}_{2} \mathrm{O} / \mathrm{fed}$. Other agricultural practices were done as recommended by the Ministry of Agriculture.

Plant height $(\mathrm{cm})$, days to heading, days to maturity, spike length, number of spike/m², number of spikelets/spike, grain weight/spike, 1000- grain weight, grain yield (ton/fed), straw yield (ton/fed), biological yield(ton/fed), and harvest index (HI\%) were studied.

All data collected were subjected to analysis of variance according to Gomez and Gomez (1984).

Table (1). Some physical and chemical properties of the experimental soils in both seasons

\begin{tabular}{|c|c|c|}
\hline Soil properties & $2013 / 2014$ & $2014 / 2015$ \\
\hline \multicolumn{3}{|l|}{ A) Mechanical analysis: } \\
\hline Sand $(\%)$ & 20.3 & 20.0 \\
\hline Silt (\%) & 26.1 & 25.3 \\
\hline Clay (\%) & 53.6 & 53.7 \\
\hline Soil texture class & Clay & Clay \\
\hline \multicolumn{3}{|l|}{ B) Chemical analysis } \\
\hline E.C $(1: 1)(d S / m)$ & 2.1 & 2.12 \\
\hline $\mathrm{p}^{\mathrm{H}}$ & 8.1 & 8.3 \\
\hline \multicolumn{3}{|l|}{ 1) Soluble cations (mg/L) } \\
\hline $\mathrm{Ca}^{++}$ & 190.5 & 190.52 \\
\hline $\mathrm{Mg}^{++}$ & 45.75 & 45.77 \\
\hline $\mathrm{K}^{+}$ & 51.32 & 51.33 \\
\hline $\mathrm{Na}^{+}$ & 201.11 & 201.22 \\
\hline \multicolumn{3}{|l|}{ 2) Soluble anions (mg/L) } \\
\hline $\mathrm{Cl}^{-}$ & 250.6 & 250.65 \\
\hline $\mathrm{HCO}_{3}^{-}$ & 262.028 & 262.033 \\
\hline $\mathrm{So}_{4}=$ & 500.51 & 500.55 \\
\hline O.M \% & 1.77 & 2.23 \\
\hline Available N (mg/kg) & 35.5 & 54.7 \\
\hline Available P (mg/kg) & 11.1 & 11.5 \\
\hline Available K (mg/kg) & 221 & 225 \\
\hline
\end{tabular}

\section{RESULTS AND DISCUSSION}

The presented results in Table (2) cleared that days to heading was significantly affected by nitrogen sources in the second season, only. It is clear that the maximum days to heading was achieved at Urea. while, the minimum was at Ammonium sulphate. 
Results listed in the same table pointed out that days to heading significantly increased by increasing nitrogen levels from zero up to $100 \mathrm{~kg}$ $\mathrm{N} / \mathrm{fed}$ in the two studied seasons. These results may be due to the role of nitrogen in vegetative growth of plant. Similar results are in agreement with those obtained by El- Hag and Shahein (2017).

Results also revealed that, days to maturity parameter was insignificantly affected by nitrogen sources in the two seasons. Whereas, this trait was gradually increased by increasing nitrogen levels up to $100 \mathrm{~kg} \mathrm{~N} / \mathrm{fed}$. The highest value was taken at $100 \mathrm{~kg} \mathrm{~N} / \mathrm{fed}$ and the lowest value at control in both seasons. Development may explain the role of nitrogen in motivating all division and elongation, the internodes elongation. However, the role of $\mathrm{N}$ in hopeful metabolic processes in wheat plant, consequently, their growth, spike beginning and grain filling is responsible for the increase of spike length, number of spikelets, grains / spike and 1000- grains weight, similar results were obtained by Selem and Abd El-Dayem (2013) Khalid and Hammad (2014) and El- Hag and Shahein (2017).

Results in the same table pointed out that, plant height was insignificantly affected by nitrogen sources in the two investigated seasons. While, there was gradually increased by increasing nitrogen levels. The tallest plants seen at 100 $\mathrm{kg} \mathrm{N} /$ fed and the shortest at control treatment. These findings may be due to nitrogen role in cell divisions and elongation. These results are agreement with those obtained by Abd El- Hameed (2012); Khaled and Hammad (2014) and ElHag and Shahein (2017).

Table (2). Effect of sources and levels of nitrogen fertilization on days to heading, days to maturity and plant height of wheat plant during 2013/2014 and 2014/2015 seasons

\begin{tabular}{|c|c|c|c|c|c|c|}
\hline \multirow{2}{*}{ Treatments } & \multicolumn{2}{|c|}{ Days to heading } & \multicolumn{2}{|c|}{ Days to maturity } & \multicolumn{2}{|c|}{ Plant height (cm) } \\
\hline & 2013/2014 & $014 / 2015$ & 2013/2014 & 2014/2015 & 2013/2014 & 2014/2015 \\
\hline \multicolumn{7}{|c|}{ A) Sources of nitrogenous fertilization } \\
\hline Urea & 102.1 & 102.1 & 143.1 & 142.6 & 91.5 & 92.1 \\
\hline $\begin{array}{l}\text { Ammonium } \\
\text { Sulphate }\end{array}$ & 101.9 & 101.6 & 143.1 & 139.6 & 92.0 & 91.3 \\
\hline $\begin{array}{l}\text { Ammonium nitrate } \\
\text { L.S.D at } 0.05\end{array}$ & $\begin{array}{l}101.9 \\
\text { N.S }\end{array}$ & $\begin{array}{l}102.0 \\
0.46\end{array}$ & $\begin{array}{c}143.2 \\
\text { N.S }\end{array}$ & $\begin{array}{c}142.9 \\
\text { N.S }\end{array}$ & $\begin{array}{l}91.8 \\
\text { N.S }\end{array}$ & $\begin{array}{l}92.2 \\
\text { N.S }\end{array}$ \\
\hline \multicolumn{7}{|c|}{ B) levels of nitrogenous fertilization (kg/fed) } \\
\hline 0 & 98.7 & 98.5 & 140.3 & 140.2 & 77.3 & 79 \\
\hline 50 & 100.9 & 100.5 & 142.3 & 137.2 & 88.5 & 88.9 \\
\hline 75 & 103.2 & 103.3 & 144.2 & 144.0 & 99.8 & 98.9 \\
\hline 100 & 105.1 & 105.4 & 145.7 & 145.5 & 101.6 & 100.3 \\
\hline L.S.D at 0.05 & 0.26 & 0.28 & 0.26 & 5.61 & 0.57 & 1.25 \\
\hline Interaction & & & & & & \\
\hline$A \times B$ & N.S. & N.S. & N.S. & N.S. & * & * \\
\hline
\end{tabular}


The results presented in Table (3) indicated that the number of spikes $/ \mathrm{m}^{2}$ was significantly affected by nitrogen sources in the two studied seasons. The maximum numbers (244.2 and 237.8) were obtained with nitrogen fertilization in form of Urea and the minimum numbers were (222.4 and 219.6) were with Ammonium sulphate form in the first and second season, respectively. These results are in agreement with those recorded by Treza et al. (2012). On the other hand, number of spike $/ \mathrm{m}^{2}$ significantly increased by increasing nitrogen levels from zero to $100 \mathrm{~kg} \mathrm{~N} / \mathrm{fed}$. These results may be due to the ability of wheat plants to produce more tillers and consequently more spike under the application of nitrogen fertilizer. Similar results were obtained by Abdel- Nour and Fateh (2011) and Nour El- Din et al. (2013) who found that number of spikes $/ \mathrm{m}^{2}$ was increased by increasing $\mathrm{N}$. levels from zero up to $75 \mathrm{~kg} \mathrm{~N} / \mathrm{fed}$.

Results also showed that spike length was insignificantly influenced by nitrogen sources during the two studied seasons and significantly increased by increasing levels of nitrogen fertilization. The tallest spikes were (12.1 and 11.9 $\mathrm{cm})$ obtained at $100 \mathrm{~kg} \mathrm{~N} / \mathrm{fed}$. Whereas, the shortest spikes $(9.9$ and9.8 $\mathrm{cm})$ with control were in the first and second seasons, respectively. Similar results are in agreement with those reported by Abd El-Hameed (2012), and Nour ElDin (2013) Mansour et al. (2016).

Results listed in Table (3) indicated that nitrogen sources significantly affected number of spike/m ${ }^{2}$ and 1000 -grain weight.While, non-significantly affected spike length, number of grain/spike, number of spikelets/spike and grain weight/spike. 
Table (3). Effect of sources and levels of nitrogen fertilization on yield components of wheat during $2013 / 2014$ and 2014/2015 seasons

\begin{tabular}{|c|c|c|c|c|c|c|c|c|c|c|c|c|}
\hline \multirow[t]{2}{*}{ Treatments } & \multicolumn{2}{|c|}{ No. of spikes $/ \mathrm{m}^{2}$} & \multicolumn{2}{|c|}{ Spike length (cm) } & \multicolumn{2}{|c|}{ No. of grains/spike } & \multicolumn{2}{|c|}{$\begin{array}{c}\text { No. of } \\
\text { spikelets/spike }\end{array}$} & \multicolumn{2}{|c|}{$\begin{array}{c}\text { Grains } \\
\text { weight/spike (g) }\end{array}$} & \multicolumn{2}{|c|}{$\begin{array}{c}\text { 1000-grain weight } \\
(\mathrm{g})\end{array}$} \\
\hline & $2013 / 2014$ & 2014/2015 & 2013/2014 & 2014/2015 & $2013 / 2014$ & 2014/2015 & $2013 / 2014$ & $2014 / 2015$ & $2013 / 2014$ & 2014/2015 & $2013 / 2014$ & $2014 / 2015$ \\
\hline \multicolumn{13}{|c|}{ A) Sources of nitrogenous fertilization } \\
\hline Urea & 244.2 & 237.8 & 11.2 & 11.0 & 56.6 & 56.8 & 20.9 & 21.1 & 2.1 & 2.1 & 34.7 & 34.9 \\
\hline Ammonium Sulphate & 222.4 & 219.6 & 11.1 & 10.8 & 56.3 & 56.3 & 20.8 & 20.8 & 2.1 & 2.1 & 35.8 & 35.2 \\
\hline Ammonium nitrate & 233.5 & 228.9 & 11.2 & 11.0 & 56.3 & 56.7 & 20.7 & 20.9 & 2.2 & 2.2 & 35.9 & 36.4 \\
\hline L.S.D at 0.05 & 1.53 & 1.74 & N.S & N.S & N.S & N.S & N.S & N.S & N.S & N.S & 0.73 & 0.46 \\
\hline \multicolumn{13}{|c|}{ B) Levels of nitrogenous fertilization (kg/fed) } \\
\hline 0 & 147.3 & 149.4 & 9.9 & 9.8 & 31.2 & 31.7 & 19.4 & 19.3 & 0.82 & 0.84 & 26.1 & 25.9 \\
\hline 50 & 190.1 & 193.0 & 10.7 & 10.5 & 49.4 & 50 & 20.5 & 20.7 & 1.7 & 1.7 & 33 & 33.1 \\
\hline 75 & 284.8 & 283 & 11.9 & 11.6 & 71.2 & 71.0 & 21.7 & 21.9 & 2.9 & 2.9 & 41.1 & 41.3 \\
\hline 100 & 292.8 & 291.4 & 12.1 & 11.9 & 73.8 & 73.7 & 21.7 & 21.8 & 3.1 & 3.1 & 41.7 & 41.7 \\
\hline L.S.D. at 0.05 & 1.78 & 1.45 & 0.12 & 0.13 & 0.47 & 0.39 & 0.29 & 0.31 & 0.04 & 0.03 & 0.57 & 0.45 \\
\hline Interaction & & & & & & & & & & & & \\
\hline$A \times B$ & * & * & N.S. & N.S. & N.S. & N.S. & * & * & * & * & * & * \\
\hline
\end{tabular}

N.S.: Not significant difference at 0.05 level of probability, ${ }^{*}$ : Significant different at 0.05 level of probability. 
Results presented in Table (4) indicated that grains, straw and biological yield were significantly affected by nitrogen sources during the two studied seasons. Results cleared that maximum grains yield values were ( 2.33 and 2.36 tons/fed) were given at Urea application in the first and second seasons respectively. While, the application of nitrogen fertilizer as Ammonium sulphate given the lowest values in the first and the second seasons. On the other side, straw yield value surpassed at Urea application followed by Ammonium nitrate in the first season and lowest value was taken at Ammonium sulphate, same trend seen in the second season. It is important to clear that biological yield achieved the highest values (5.82 tons/fed) at Urea fertilization in the two studied seasons and the lowest values were (5.59 and 5.56 tons/fed) were given at ammonium sulphate in the first and second seasons respectively. It is important to clear that harvest index (\%) was insignificant at $5 \%$ level during the first season and significant in the second season. The highest numbers were given at Ammonium sulphate during the second investigated season, Treza et al. (2012) cleared that grain yield was insignificantly affected by nitrogen sources. While, Mohammed et al. (2015) found that grain, straw and biological yields were significantly affected by nitrogen sources and they pointed out that the highest values were given at Di-ammonium phosphate (DAP) followed by Ammonium sulphate. while, the lowest values were at Urea.

Results listed in Table (4) pointed out that the application of the four different levels of nitrogen fertilization had significant effect on grain, straw and biological yields during the two investigated seasons. All values of parameters were gradually increased by increasing nitrogen fertilization from zero up to 100 $\mathrm{kg} \mathrm{N} / \mathrm{fed}$. Similar results are in agreement with those obtained by Ali et al. (2011) who concluded that among N. levels, the highest grain yield (3.848 tons/fed) was obtained by application of (180 kg N/fed). In addition, results recorded that Harvest Index (\%) parameter was significantly affected by nitrogen levels in the first and second season. However, the highest values were recorded at 75 and $100 \mathrm{~kg} \mathrm{~N} / \mathrm{fed}$ in the first and the second seasons. While, the lowest values were recorded at control. Similar findings are in agreement with that obtained by Selem and Abd El- Dayem (2013) and El- Hag and Shahein (2017).

Results in Table (4) cleared that the interaction between nitrogen sources and nitrogen fertilizer levels had significant effect on grain yield during both seasons. While, straw and biological yields as well as $\mathrm{HI}$ insignificantly affected by the interaction between $\mathrm{N}$ sources and levels in both seasons. These results cleared that nitrogen sources and nitrogen fertilization levels act independently on the pervious mentioned characters under this study. 
Table (4). Effect of three sources and four levels of nitrogen fertilization on grain, straw and biological yields (ton/fed) as well as harvest index (\%) of wheat during $2013 / 2014$ and $2014 / 2015$ seasons

\begin{tabular}{|c|c|c|c|c|c|c|c|c|}
\hline \multirow{2}{*}{ Treatments } & \multicolumn{2}{|c|}{ Grains yield (ton/fed) } & \multicolumn{2}{|c|}{ Straw yield (ton/fed) } & \multicolumn{2}{|c|}{ Biological yield (ton/fed) } & \multicolumn{2}{|c|}{ H.I (\%) } \\
\hline & $2013 / 2014$ & $2014 / 2015$ & $2013 / 2014$ & $2014 / 2015$ & $2013 / 2014$ & $2014 / 2015$ & $2013 / 2014$ & $2014 / 2015$ \\
\hline \multicolumn{9}{|c|}{ Sources of nitrogenous fertilization } \\
\hline Urea & 2.33 & 2.36 & 3.48 & 3.46 & 5.82 & 5.82 & 38.8 & 39.1 \\
\hline Ammonium Sulphate & 2.27 & 2.29 & 3.33 & 3.27 & 5.59 & 5.56 & 39.2 & 39.9 \\
\hline Ammonium nitrate & 2.30 & 2.32 & 3.43 & 3.42 & 5.73 & 5.74 & 38.8 & 39.0 \\
\hline L.S.D 0.05 & 0.01 & .011 & 0.07 & 0.05 & 0.07 & 0.04 & N.S & 0.49 \\
\hline \multicolumn{9}{|c|}{ Levels of nitrogenous fertilization (kg/fed) } \\
\hline 0 & 1.07 & 1.08 & 2.82 & 2.82 & 3.88 & 3.89 & 27.8 & 27.9 \\
\hline 50 & 2.10 & 2.15 & 3.35 & 3.32 & 5.44 & 5.47 & 38.6 & 39.4 \\
\hline 75 & 3.00 & 3.01 & 3.71 & 3.64 & 6.71 & 6.65 & 44.7 & 45.3 \\
\hline 100 & 3.04 & 3.05 & 3.78 & 3.77 & 6.82 & 6.82 & 44.5 & 44.8 \\
\hline $\begin{array}{l}\text { L.S.D0.05 } \\
\text { Interaction }\end{array}$ & 0.01 & 0.013 & 0.06 & 0.07 & 0.06 & 0.07 & 0.46 & 0.53 \\
\hline$A \times B$ & * & * & N.S. & N.S. & N.S. & N.S. & N.S. & N.S. \\
\hline
\end{tabular}

N.S.: Not significant difference at 0.05 level of probability, *: Significant different at 0.05 level of probability. 
Results presented in Table (5) pointed out that plant height was significantly influenced by the interaction between nitrogen sources and nitrogen levels in the $1^{\text {st }}$ and $2^{\text {nd }}$ seasons. It's important to remember that the highest plants were $(101.7$ and $100.9 \mathrm{~cm}$ ) given when applied $100 \mathrm{~kg} \mathrm{~N} / \mathrm{fed}$ of ammonium sulphate in the first and second season, respectively. These results may be attributed to on important of nitrogen in cell division and elongation.

Results also cleared that number of spikes $/ \mathrm{m}^{2}$ was significantly affected by nitrogen sources and nitrogen levels interaction during the two investigated seasons. Whereas, the results detected superiority when nitrogen levels applied at $100 \mathrm{~kg} \mathrm{~N} / \mathrm{fed}$ as urea formation in the first and second season. However, weight of grains/spike was significantly affected by the interaction between nitrogen sources and levels in the first and second seasons. The highest value was (3.12 and $3.1 \mathrm{~g}$ ) was given at $100 \mathrm{~kg} / \mathrm{fed}$ as ammonium nitrate in the first and second seasons, respectively. While, $100 \mathrm{~kg} \mathrm{~N} / \mathrm{fed}$ of Ammonium sulphate form came in the first and equaled in the second rank. On the other side, 1000grain weight was significantly varied by the interaction between nitrogen sources and nitrogen levels in the two studied seasons. The highest weight $(41.7 \mathrm{~g})$ was taken at $100 \mathrm{~kg} \mathrm{~N} / \mathrm{fed}$ as ammonium nitrate in the first season and $(41.87 \mathrm{~g})$ of ammonium sulphate form in the second season. While, the highest weight were taken at control.

Also, results presented in Table (5) showed that grain yield was significantly varied by the interaction between nitrogen sources and nitrogen levels. The greatest grains yield (3.08 and 3.10 tons /fed) was taken under Nfertilizer in form as Urea at the rate of $100 \mathrm{~kg} \mathrm{~N} / \mathrm{fed}$ in the first and second seasons respectively. These findings may be due to increase in yield components during the investigation. 
Table (5). The interaction effect between nitrogen sources and nitrogen levels on plant height $(\mathrm{cm}) \mathrm{No}$. of spike $/ \mathrm{m}^{2}$, grains weight / spike (g) and 1000-grain weight (gm) and grain yield (t/fed) during 2013/2014 and 2014/2015 seasons

\begin{tabular}{|c|c|c|c|c|c|c|c|c|c|c|c|}
\hline \multirow{2}{*}{$\begin{array}{l}\text { Sources of } \\
\text { nitrogenous } \\
\text { fertilization }\end{array}$} & \multirow{2}{*}{$\begin{array}{c}\text { Levels of } \\
\text { nitrogenous } \\
\text { fertilization } \\
(\mathrm{kg} / \mathrm{fed})\end{array}$} & \multicolumn{2}{|c|}{ Plant height (cm) } & \multicolumn{2}{|c|}{ No. of spikes $/ \mathrm{m}^{2}$} & \multicolumn{2}{|c|}{$\begin{array}{c}\text { Grains weight/spike } \\
(\mathrm{g})\end{array}$} & \multicolumn{2}{|c|}{ 1000- grain weight $(g)$} & \multicolumn{2}{|c|}{ Grain yield (ton/fed) } \\
\hline & & $2013 / 2014$ & $2014 / 2015$ & $2013 / 2014$ & $2014 / 2015$ & $2013 / 2014$ & $2014 / 2015$ & $2013 / 2014$ & $2014 / 2015$ & $2013 / 2014$ & $2014 / 2015$ \\
\hline \multirow{4}{*}{ Urea } & 0 & 77.5 & 80.4 & 150.6 & 153.9 & 0.83 & 0.83 & 25.9 & 25.7 & 1.07 & 1.09 \\
\hline & 50 & 87.8 & 89.1 & 198.7 & 205.4 & 1.6 & 1.6 & 30.6 & 31.3 & 2.15 & 2.19 \\
\hline & 75 & 99.2 & 98.8 & 297.7 & 293.0 & 2.9 & 2.9 & 40.8 & 41.2 & 3.03 & 3.05 \\
\hline & 100 & 101.5 & 100.3 & 304.2 & 302.1 & 3.1 & 3.1 & 41.3 & 41.5 & 3.08 & 3.10 \\
\hline \multirow{4}{*}{$\begin{array}{l}\text { Ammonium } \\
\text { sulphate }\end{array}$} & 0 & 78.0 & 77.9 & 143.7 & 145.0 & 0.83 & 0.81 & 26.2 & 25.7 & 1.07 & 1.08 \\
\hline & 50 & 88.4 & 87.3 & 180.9 & 180.7 & 1.7 & 1.6 & 34.3 & 32.2 & 2.05 & 2.11 \\
\hline & 75 & 100.1 & 99.2 & 272.7 & 272 & 2.9 & 2.9 & 40.9 & 41.3 & 2.96 & 2.98 \\
\hline & 100 & 101.7 & 100.9 & 281.2 & 280.2 & 3.1 & 3.1 & 41.7 & 41.8 & 2.99 & 3.00 \\
\hline \multirow{4}{*}{$\begin{array}{l}\text { Ammonium } \\
\text { nitrate }\end{array}$} & 0 & 76.4 & 80.0 & 147.8 & 149.4 & 0.82 & 0.87 & 26.1 & 26.5 & 1.07 & 1.07 \\
\hline & 50 & 89.4 & 90.6 & 190.9 & 193 & 1.7 & 1.8 & 34.1 & 35.8 & 2.09 & 2.15 \\
\hline & 75 & 100.1 & 98.5 & 284 & 284 & 3.0 & 2.9 & 41.5 & 41.5 & 3.00 & 3.01 \\
\hline & 100 & 101.4 & 99.6 & 293 & 291.9 & 3.1 & 3.1 & 42.1 & 41.7 & 3.03 & 3.05 \\
\hline \multicolumn{2}{|c|}{ L.S.D at 0.05} & 0.98 & 2.17 & 3.09 & 2.51 & 0.07 & 0.05 & 0.98 & 0.77 & 0.02 & 0.02 \\
\hline
\end{tabular}




\section{CONCLUSION}

It was concluded form the present results that sowing wheat cultivar Gemiza 11 with fertilizing $100 \mathrm{~kg} \mathrm{~N} / \mathrm{fed}$ in form as Urea which increased yield and its components of wheat crop under El- Beheira Governorate conditions.

\section{REFERENCES}

Abd El-Hameed, I. M. (2012). Response of four new bread wheat (Triticum aestivum L.) cultivars to nitrogen fertilizer levels under sprinkler irrigation system in sandy soils. Egypt. J. Agron., 34(1) 1-17.

Abdel-Nour, N. A. R. and H. S. A. Fateh (2011). Influence of sowing date and nitrogen fertilization on yield and its components in some bread wheat genotypes. Egypt. J. Agric. Res., 89 (4):1-8.

Ahmed, S. M.M., A.A. Abdul Galil, H.A. Basha and A.A.E. Mowafy (2009). Response of wheat to fertilization under sandy soil condition. Zagazig J.Agric.Res., 36(4):1045-1067.

Ali, A.,A. W.H. Ahmad, T. Syed Khaliq and M. A. Aziz (2011). Effect of nitrogen on growth and yield components of wheat (report). Science International (Lahore), 24:331-332.

Chapman, H.D. and P.F. Pratt (1978). Methods of analysis for soil plant and waters M.E.A. Univ. of California Div. Agric. Sci. Priced publication, 4043.

El- Hag, A.A. and M.E.A. Shahein (2017). Effect of different nitrogen rates on productivity and quality traits of wheat cultivars. Egypt. J. Agro., 39(3):321 - 335.

El-Hawary, M.N. A. and A. M. Shahein (2015). Response of some wheat cultivars to sowing on bed under different nitrogen levels on some agronomic and quality traits. J. Agr. Kafrelsheikh Univ., 41(4):1340-1354.

FAO (2016). Food Agriculture Organization. www.faostat.org.

Gomez, K.A. and A.A. Gomez (1984). Statistical procedures for Agricultural Research. ( $2^{\text {nd }}$ ed). An International Rice Research Institute J. Wiley and Sons, New York, USA. pp. 377-434.

Khaled, M.A. and S. M. Hammad (2014). Effect of nitrogen and potassium levels on yield and its components of four new bread wheat cultivars. J. Plant Production, Mansoura Univ., 5(1): 95- 105.

Mansour, H.A.G., S.K. Pibars. M. S. Gaballah and K. A. S. Mohammed (2016). Effect of different nitrogen fertilizer levels and wheat cultivars on yield and its components under sprinkler irrigation system management in sandy soil. Inter. J. Chem Tech Res., I.9(9):1-9.

Mohammed, Q. M. Khursheed and Q. Mahammad (2015). Effect of different nitrogen fertilizers on growth and yield of wheat. Khursheed, 27(5):33-44.

Nour El-din, N.A., H.S. Saudy, F. Ashmawy and H.M. Saed (2013). Grain yield response index of bread wheat cultivars as influenced by nitrogen levels. Annals of Agric. Sci., 58(2):147-152.

Selem, S. A. and S. M. Abd EI -Dayem (2013). Response of some wheat cultivars to nitrogen fertilizer levels. J. Plant Production, Mansoura Univ., 4(5): $721-731$. 
Tereza, F. M., G.T. Jon, M.A Luis, G.M. Carmen, G. M. Begona and M.E. Jose (2012). Ammonium as sole $N$ source improves grain quality in wheat. J. Sci. Food and Agric., 93(9):33-45.

\section{الملخص العربي \\ إنتاجية القمح تحث مصادر ومستويات مختلفة من التسميد التيتروجيني}

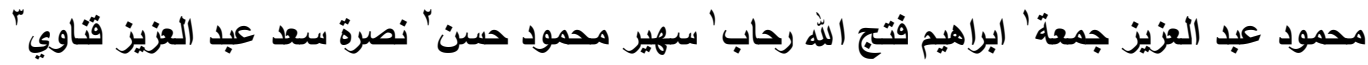

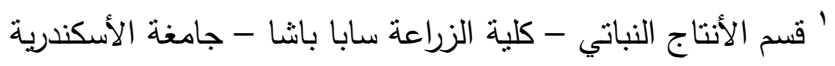
' قسم بحوث القمح - معهد المحاصيل الحقلية - مركز البحوث الزراعية - البحيرة 'ب توزراة الزراعة - البحيرة

أجريت تجربنان حقليتان بالمزرعة البحثية - محطة البحوث الزراعية بإيتاى البارود - محافظة البحيرة - خلال

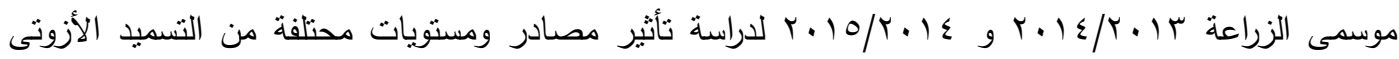
على المحصول ومكوناته لصنف قمح الخبز "جميزة || | " وكان التصميم المستخدم القطع المنشقة مرة واحدة حيث لرديث

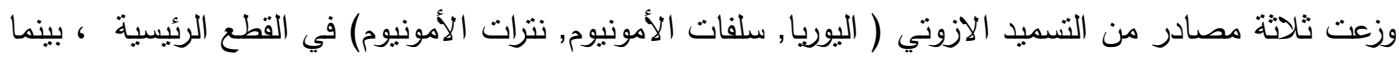

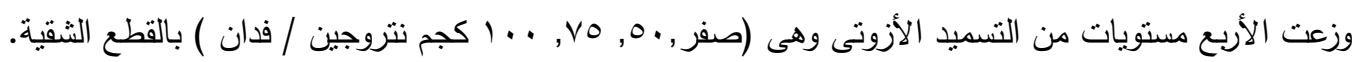

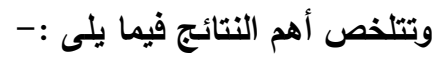
- تأثز عدد الأيام حتى طرد السنابل معنوياً بمصادر التسميد النتروجيني المختلفة خلال الموسم الثانى فقط , ولم

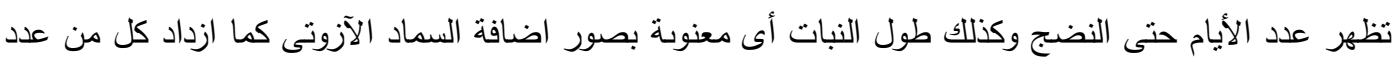
الأيام حتى طرد السنابل ، وعدد الأيام حتى النضج تدريجياً بزيادة مستوى التسميد الأزوتى خلال الموسمين ،

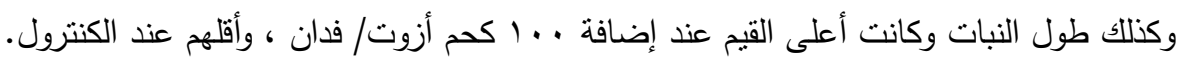

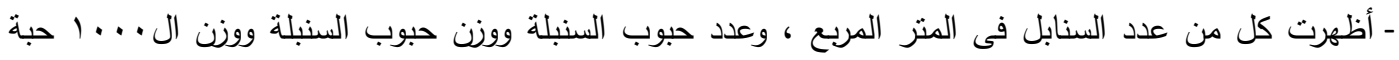

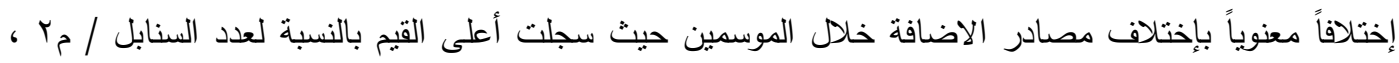

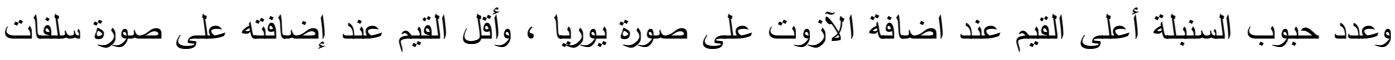

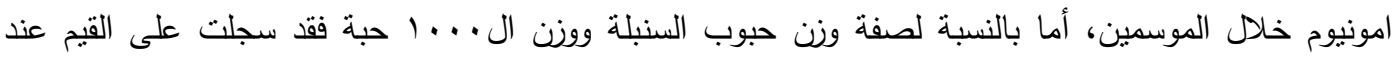

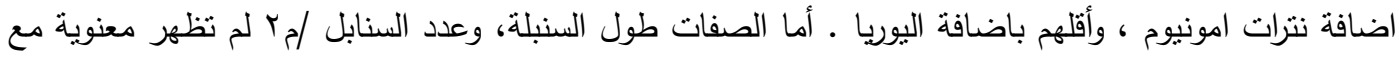
صور الاضافة.

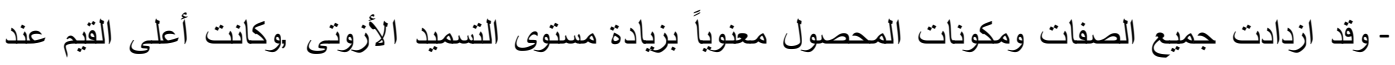
المستوى · . اكجم نبتروجين/فدان ، وأقلهم عند الكنترول. - أظهرت صفات محصول الحبوب والقش والبيولوجى اختلافاً معنوياً مع اختلاف صور الاضافة فى الموسمين وكانت أعلى القيم عند اضافة اليوريا أما صفة دليل الحصاد فقد اظهرت اختلافاً معنوياً فى الموسم الثانى فقط. كما ازدادت تلك الصفات تدريجياً بزيادة المستوى التسميد الآزوتى معنوياً خلال موسمى الدراسة , وكان أعلى محصول 
حبوب وقش وبيولولوجى عند اضافة . . 1 كجم نبتروجين/ فدان ، وأقل القيم عند مستوى صفر نيتزوجين/فدان ،

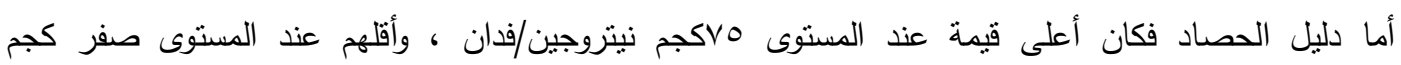
نيتروجين/فدان.

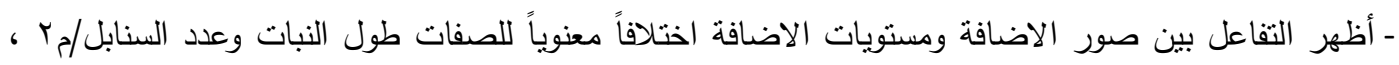

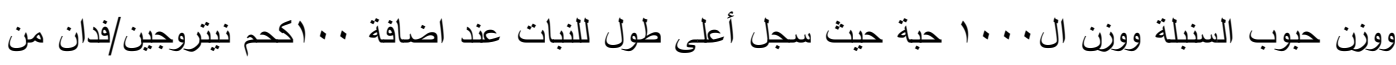

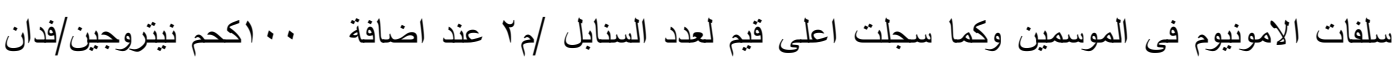

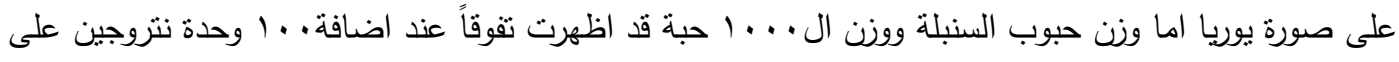
صورة نترات الامونيوم. - مبك. - اختلفت صفة محصول الحبوب للفدان معنوياً مع التفاعل بين صور ومستويات الاضافة حيث اعطى اعلى لإنى محصول حبوب عند اضافة . . اكحم نيتروجين/فدان من سماد اليوريا خلال موسمى الدراسة.

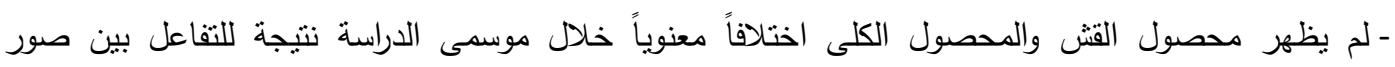
ومستويات الأزوت. 
J. Adv. Agric. Res. (Fac. Agric. Saba Basha) 